\title{
Communities and occurrences of Squamata reptiles in different vegetation types of the Serra de São José, Minas Gerais, Brazil
}

\author{
Celso Henrique Varela Rios ${ }^{1}$, Iara Alves Novelli ${ }^{1 *}$, Alexandre de Assis Hudson'², Pilar Cozendey ${ }^{\text {, }}$ \\ Lúcio Campos Lima ${ }^{I}$ \& Bernadete Maria de Sousa ${ }^{I}$ \\ ${ }^{1}$ Laboratório de Herpetologia, Departamento de Zoologia, Universidade Federal de Juiz de Fora, 36.036-900, \\ Juiz de Fora, Minas Gerais, Brazil. \\ ${ }^{2}$ Instituto Chico Mendes de Conservação da Biodiversidade, Floresta Nacional de Ritápolis, Ritápolis, MG, Brazil. \\ *Corresponding author: Iara Alves Novelli, e-mail: iaranovelli27@gmail.com
}

VARELA RIOS, C.H.V., NOVELLI, I.A., HUDSON, A.A., COZENDEY, P., LIMA, L.C., SOUSA, B.M. Communities and occurrences of Squamata reptiles in different vegetation types of the Serra de São José, Minas Gerais, Brazil. Biota Neotropica. 17(1): e20150103. http://dx.doi.org/10.1590/1676-0611-BN-2015-0103

\begin{abstract}
The objective of the present study was to learn which species of Squamata reptiles occur in Protected Area São José, in Tiradentes, Minas Gerais, Brazil. Between November 2009 and December 2010 reptiles were captured. In total 157 specimens were recorded of 29 species, 16 snakes, 12 lizards and one amphisbaena. Among the snakes, Dipsadidae showed the greatest richness, with a total of nine species. The group of snakes had the highest number of species present in the community, but $79 \%$ of sampled specimens were lizards, Enyalius bilineatus being the most abundant species, with $21 \%$ of occurrence. The area with the highest richness was the Cerradão. The lower abundance was found in the Gallery Forest area $(\mathrm{n}=14)$, but it was the vegetation type with the highest equitability. Areas of Cerradão and Cerrado sensu strictu showed the most similarity. In these areas five species were recorded in common, Bothrops neuwiedi $(\mathrm{n}=3)$ being the only species of snake, and the two species of lizards most abundant in both environments were Enyalius bilineatus $(\mathrm{n}=32)$ and Ameivula ocellifera $(\mathrm{n}=19)$. Ophiodes striatus and Xenodon merremii were common to Cerradão and Dirty Field areas. There was no species recorded that were common to the environments of Cerrado and Dirty Field but two species not sympatric were found of the same genus, Tropidurus torquatus, which was found only in the Cerrado sensu strictu and Tropidurus itambere exclusively in Dirty Field. Since none of the rarefaction curves reached full asymptote, this highlights the need for further study due to the high probability of new species being recorded for the studied area.
\end{abstract}

Keywords: Taxocenosis, Squamata, Campo das Vertentes, Inventory, Neotropical region.

\section{Comunidades e ocorrência de Répteis Squamata em diferentes tipos de vegetação da Serra de São José, Minas Gerais, Brasil}

Resumo: O presente estudo teve como objetivo conhecer quais espécies de répteis Squamata ocorrem nas diferentes fitofisionomias da Área de Proteção Ambiental Serra de São José, Tiradentes, microrregião Campo das Vertentes, Sudeste de Minas Gerais, Brasil. Entre novembro de 2009 e dezembro de 2010 os répteis foram capturados utilizando-se de armadilhas de interceptação e queda e de funil instaladas em 10 pontos amostrais, sendo três em Mata de Galeria, três em Cerrado sensu strictu, três em Cerradão e um em Campo Sujo aberto. Durante um ano as armadilhas ficaram abertas ininterruptamente e foram amostradas 300 horas de procura limitada por tempo. Também foram realizados encontros ocasionais com registros fotográficos dos espécimes. Ao todo foram registrados 157 espécimes pertencentes a 29 espécies, sendo 16 de serpentes, 12 de lagartos e uma de anfisbena. Entre as serpentes, Dipsadidae apresentou a maior riqueza, com um total de nove espécies. O grupo das serpentes foi o com maior número de espécies presentes na comunidade, mas $79 \%$ dos espécimes amostrados eram lagartos, sendo Enyalius bilineatus a espécie mais abundante, com $21 \%$ de ocorrência. A menor abundância foi encontrada na área de Mata de Galeria ( $\mathrm{n}=14)$, mas foi a fitofisiomia que apresentou a maior equitabilidade. $\mathrm{Na}$ área de Cerradão foi encontrada a maior riqueza, com 13 espécies registradas. As áreas de Cerradão e Cerrado sensu strictu foram as que apresentaram maior similaridade. Nestas áreas foram registradas cinco espécies em comum, sendo Bothrops neuwiedi $(\mathrm{n}=3)$ a única espécie de serpente, e as duas espécies de lagartos mais abundantes nos dois ambientes foram Enyalius bilineatus $(\mathrm{n}=32)$ e Ameivula ocellifera $(\mathrm{n}=19)$. Ophiodes striatus e Xenodon merremii foram comuns às áreas Cerradão e Campo Sujo. Não houve registro de espécie que fosse comum aos ambientes de Cerrado e Campo Sujo, mas foram encontradas duas espécies pertencentes ao mesmo gênero não simpátricas, como Tropidurus torquatus que foi encontrado apenas no Cerrado sensu strictu e Tropidurus itambere exclusivo do Campo sujo. Notomabuya frenata foi encontrada em todos os ambientes, exceto no Campo sujo, único local onde foi encontrado Aspronema dorsivittatum. Como nenhuma das curvas de rarefação atingiu a assíntota plena, evidencia-se a necessidade de mais estudos devido à alta probabilidade de registro de novas espécies para a área estudada.

Palavras-chaves: Taxocenose, Squamata, Campo das Vertentes, Inventário, Região Neotropical. 


\section{Introduction}

Reptiles form a prominent group in almost all terrestrial assemblages, with more than 10,391 known species worldwide (Uetz 2016). In Brazil, there are 773 naturally occurring and reproducing species of reptiles (Costa \& Bérnils 2015), which is the second largest number among all the countries of the world (Paglia et al. 2010). However, approximately one in five species of reptiles is endangered and, in the state of Minas Gerais, Brazil, the same proportion is still classified as data-deficient (Bérnils et al. 2009). These results reinforce the need for attention and research in tropical areas that exhibit the most dramatic rates of habitat loss (Böhm et al. 2013).

The Atlantic Forest and Cerrado biomes of Brazil have been recognized as "hotspots" for studying and conserving the world's diversity (Mittermeier et al. 2004). The greatest threats to Brazilian herpetofauna are concentrated in these phytogeographical domains and mainly result from habitat loss and degradation. These are critical situations for lizards and snakes in the remaining savanna and rocky fields of the states of São Paulo and Minas Gerais (Paglia et al. 2010). In some areas of Minas Gerais, these domains still require systematic sampling of herpetofauna with wide geographical coverage (Bérnils et al. 2009).

The remnants of the Atlantic Forest in Minas Gerais have been identified as being of interest for conservation because of high anthropogenic pressure caused by urbanization and deforestation (Drummond et al. 2005). Similarly, the Cerrado has suffered sharp changes due to its conversion to pasture, monocultures or other agricultural activities (Drummond et al. 2009; Marinho-Filho et al. 2010; Araújo \& Almeida-Santos 2011). Studies on the herpetofauna of Minas Gerais have concentrated mainly on amphibians (Bérnils et al. 2009) and much of the knowledge about the reptile fauna of the Cerrado and Atlantic Forest of Minas Gerais is still at an initial limited stage.

Through expansion of reptiles inventories (Cruz et al. 2014; Lucas et al. 2016; Novelli et al. 2012; Sousa et al. 2010; São Pedro \& Pires 2009; Silveira et al. 2010), it has been found that there is high diversity of reptiles in the Cerrado biome (Brites \& Baub 1988; Recoder \& Nogueira 2007). These studies have even shown that the distribution of some species is increasing (Santos et al 2009; Novelli et al. 2011). However, these studies are still scarce, considering the size and the variety of habitats in the Cerrado. This shortage becomes greater with regard to transition areas between the Cerrado and other biomes (Bertolucci et al. 2009; Sousa et al. 2010; Lucas et al. 2016).

The need for greater effort towards studying the diversity and distribution patterns of reptiles has been pointed out, given that there are still major gaps in knowledge regarding the composition of the fauna of Minas Gerais (Bérnils et al 2009). Among the 112 priority areas for biodiversity conservation in Minas Gerais that have been defined (Drummond et al. 2005), the Serra de São José is regarded as one of the highest-priority areas for nature conservation within the state (Probio 2004). This area is located in a transition region between the savannas of central Brazil and the semi-deciduous forests of the southeast and south of the country (Oliveira-Filho \& Machado 1993).

The aim of the present study was to make an inventory of the Squamata fauna and contribute information on the composition of species in four different vegetation types in the environmental protection area of Serra de São José, in the municipality of Tiradentes, and thus increase the knowledge of the herpetofauna of Minas Gerais, Brazil.

\section{Methodology}

\section{Study área}

The Serra de São José is located in the region of the Campo das Vertentes, in the basin of Rio das Mortes, in the southeast of the state of Minas Gerais. The Serra (mountain range) extends for about $12 \mathrm{~km}$ between the municipalities of Prados, Coronel Xavier Chaves and Santa Cruz de Minas, passing through São João del Rei and Tiradentes $\left(21^{\circ} 00^{\prime} 21^{\circ} 02^{\prime} \mathrm{S}\right.$ $44^{\circ} 00^{\prime} 44^{\circ} 15^{\prime}$ W) (Oliveira-Filho \& Machado 1993). The Serra region includes three protected areas administered by the State Forestry Institute: Environmental Protection Area (APA) of Serra de São José, Dragonflies State Wildlife Refuge of Serra de São José and Special Protection Area of Serra de São José.

The Serra de São José consists of a quartzite and sandstone massif at altitudes of 900-1430 m. The vegetation of the APA Serra de São José is quite diversified, with occurrence of semi-deciduous montane forest that belongs to the Atlantic Forest domain (Veloso et al. 1991) and also typical Cerrado vegetation (Silva et al. 2011). Above the altitude of $1250 \mathrm{~m}$, the terrain consists predominantly of high meadows. The peaks of the range and a large part of its flanks are covered by rock fields vegetation, interrupted by gallery forest and small bodies of latosol with Cerrado vegetation (Silva et al. 2011). A belt of Cerrado dry forest of around $1 \mathrm{~km}$ in width extends along the southern border, while the northern border mainly comprises plantations in Cerrado areas (Alves \& Kolbek 2009).

The average annual temperature is $22^{\circ} \mathrm{C}$, and the average in the coldest months is $15^{\circ} \mathrm{C}$. The area fits into the climatic type Cwb according to the Köppen scale, i.e. moderate subtropical humid, with two distinct seasons: one cold and dry (April to September) and another hot and rainy (October to May). The area forms part of the Andrelândia plateau, which is characterized by hills with convex and tabular summits and convex slopes (Carvalho 1987 Oliveira-Filho \& Machado 1993; Alves \& Kolbek 2009).

\section{Sampled habitats}

The sites selected for sampling were distributed into three areas of the APA Serra de São José: one in the north and two in the south. We sampled four types of vegetation: Cerrado sensu strictu, "Cerradão", gallery forest and fields with sparse shrubs. The northern region consists of a small area of Gallery forest at the Água Santa bathing area, one of Cerrado sensu strictu near to the Mangue trail entrance and another of Cerradão (large-vegetation Cerrado) near to the entrance to the head office of the bathing area. South of the mountains, traps were installed in two remote areas, 2.5 kilometers apart. One was located to the east of the forest called Bosque da Mãe D'Água (Alves 1991), and consisted of three parts: one in the Cerrado sensu strictu area and two in gallery forest. The other region was located at the western end of the mountain, near the Mangue trail. In this place, known as Coliseum, four plots were installed, one in the Cerrado sensu strictu, two in Cerradão and one in fields with sparse shrubs.

\section{Sampling methods}

The Squamata reptile sampling was conducted once a week between November 2009 and November 2010. Sets of pitfall traps were installed, with interception or guiding fences (AQs) as proposed by Greenberg et al. (1994) and Cechin \& Martins (2000) and with funnel traps (FTs) as described by Hudson (2007), at 10 sampling points. Each sampling point consisted of $100 \mathrm{~m}$ of fence interception ( $1 \mathrm{~m}$ high), 10 funnel traps and five 20-liter buckets, in alternating funnel and bucket pairs. A total of 10 sets of traps were installed in the four different vegetation types, thus totaling $50 \mathrm{AQs}$, $100 \mathrm{FTs}$ and $1000 \mathrm{~m}$ of guiding fence.

In addition to these sampling methods, trap specimens were also caught and collected through a limited-time search during the diurnal period (from 8:00 to 18:00), covering the various microhabitats. Specimens were sought on trees, in burlap, under fallen logs and in hollow trees, termite nests, burrows and rodents' galleries (Bernarde 2008). The specimens occasionally found by staff members or other people were used to supplement the list of species, and these were also considered to be among the four collection methods used by Zanella \& Cechin (2006).

Specimens found during maintenance tasks on the farm known as Coliseum (weeding, maintenance of fence posts, planting and cleaning) and during other everyday jobs in the region were also registered in the 
present study. One snake specimen was registered near one of the capture and collection areas, at a location that a farm employee reported, and other specimens were photographed in the APA Serra de São José at locations outside of the sampling areas (BM Sousa, personal observation).

The specimens that were caught or collected alive were photographed and were mostly released near the capture site. No more than five specimens of each species were collected for identification and registration, and these were deposited as voucher specimens in the Herpetological Collection, Reptile Section, of the Federal University of Juiz de Fora (CHUFJF - Reptiles).

In this paper, the term "lizard" is used in the traditional ecological sense, i.e. Squamata with eyelids and at least traces of legs, which obviously do not constitute a monophyletic group. The taxonomy adopted was that of Frost et al. (2001), with some updates provided by Carrasco et al. (2012). In order to standardize the results, the taxonomy recommended by the Brazilian Society of Herpetology (Costa \& Bérnils 2015) was also used. To identify specimens, field guides, keys and descriptions in papers (Peters et al. 1986, Rodrigues 1987; Ávila-Pires 1995; Doan \& Arriaga 2002) were used. For Teiidae, a paper by Pyron et al. (2013) was used; and for Scincidae, the nomenclature proposed by Hedges \& Conn (2012) was used. Representative specimens are listed in Appendix 1.

\section{Data analysis}

Statistical analyses were performed on species diversity and similarity between habitats. The richness of species of the four vegetation types sampled was compared by means of rarefaction curves in the EstimateS 9.1.0 software (Colwell 2013) with a thousand randomizations, through the Jackknife 1 estimator. The curves were generated through the bootstrap method, because this uses data on all species, i.e. not limited to rare species (Santos 2003), considering that snake fauna are often recorded with only one or two specimens of each species. The richness in the four vegetation types sampled was compared by means of species rarefaction curves. The similarity was studied through Jaccard's qualitative similarity index (Magurran 2004). The diversity was estimated using Margalef's index (DMg), which expresses richness weighted by the range of sample size; Simpson's index (1/D), which measures dominance influenced by the most common species, i.e. the likelihood that two individuals caught randomly would belong to the same species; and Shannon's index (H'), which places a value on the proportional abundance of species, emphasizing richness and homogeneity. The latter was used to calculate Shannon's equitability index (J).

\section{Results}

Overall, the sampling effort for this study lasted for 12 months, involving uninterrupted open traps and 52 field trips, totaling 8640 hours of bucket sampling and 300 hours of time-limited hunts. We recorded a total of 157 specimens belonging to 13 families and 29 species of Squamata reptiles: one species of amphisbaena $(n=3), 12$ species of lizards $(n=123)$ and 16 snakes $(n=31)$ (Figures 1 to 3$)$. Considering first-order jackknife estimators, the richness estimated for the study area, in the four vegetation types sampled was approximately 32 species (Figures 4 and 5). None of the species rarefaction curves reached the asymptote.

In this study, snakes contributed the largest number of species within the APA reptile community, but numerically, $79 \%$ of the individuals caught belonged to lizard families. Among the snakes, the family Dipsadidae was the richest, with a total of nine sampled species. For the lizards, the greatest richness was found in the family Teiidae $(\mathrm{n}=3)$. The most abundant families were Teiidae $(n=35)$, Leiosauridae $(n=32)$ and Tropiduridae $(n=28)$, which accounted for $61 \%$ of all the Squamata reptiles studied (Table 1).

Although fields with sparse shrubs were only sampled at one point, this vegetation type presented important results because of the six species
Table 1. Squamata Reptile species sampled in the Serra de São José, Tiradentes, Minas Gerais, and their abundances according to vegetation type. GF $=$ Gallery Forest, $\mathrm{CD}=$ Cerradão, $\mathrm{CE}=$ Cerrado sensu strictu, $\mathrm{CS}=$ Dirty field, $\mathrm{SI}=$ no information about the location of collection / capture and ST = subtotal.

\begin{tabular}{|c|c|c|c|c|c|c|}
\hline & GF & CD & $\mathbf{C E}$ & DF & SI & ST \\
\hline \multicolumn{7}{|l|}{ Amphisbaenidae } \\
\hline $\begin{array}{l}\text { Leposternon microcephalum } \\
\text { Wagler in Spix, } 1824\end{array}$ & & 1 & & & 2 & 3 \\
\hline \multicolumn{7}{|l|}{ Anguidae } \\
\hline Ophiodes striatus (Spix, 1825) & 1 & 1 & & 2 & 1 & 5 \\
\hline \multicolumn{7}{|l|}{ Gekkonidae } \\
\hline $\begin{array}{l}\text { Hemidactylus mabouia } \\
\text { (Moreau de Jonnès, 1818) }\end{array}$ & & & & & 1 & 1 \\
\hline \multicolumn{7}{|l|}{ Gymnophthalmidae } \\
\hline $\begin{array}{l}\text { Ecpleopus gaudichaudi } \\
\text { Duméril \& Bibron, } 1839\end{array}$ & 2 & 4 & & & & 6 \\
\hline Heterodactylus imbricatus Spix, 1825 & 1 & 3 & & & & 4 \\
\hline \multicolumn{7}{|l|}{ Leiosauridae } \\
\hline Enyalius bilineatus Duméril \& Bibron, 1837 & 5 & 10 & 17 & & & 32 \\
\hline \multicolumn{7}{|l|}{ Mabuyidae } \\
\hline Aspronema dorsivittatum (Cope, 1862) & & & & 2 & & 2 \\
\hline Notomabuya frenata (Cope, 1862) & 1 & 1 & 8 & & & 10 \\
\hline \multicolumn{7}{|l|}{ Teiidae } \\
\hline Ameiva ameiva (Linnaeus, 1758) & & & & 13 & & 13 \\
\hline Ameivula ocellifera (Spix, 1825) & & 1 & 18 & & & 19 \\
\hline Salvator merianae (Duméril \& Bibron, 1839) & & 1 & 2 & & & 3 \\
\hline \multicolumn{7}{|l|}{ Tropiduridae } \\
\hline Tropidurus itambere Rodrigues, 1987 & & & & 2 & & 2 \\
\hline Tropidurus torquatus (Wied, 1820) & & & 26 & & & 26 \\
\hline SQUAMATA: SERPENTES & & & & & & 126 \\
\hline \multicolumn{7}{|l|}{ Boidae } \\
\hline Epicrates crassus Cope, 1862 & & & & & 1 & 1 \\
\hline \multicolumn{7}{|l|}{ Colubridae } \\
\hline Chironius flavolineatus (Jan, 1863) & & 1 & & & & 1 \\
\hline Chironius quadricarinatus (Boie, 1827) & & 1 & & & & 1 \\
\hline \multicolumn{7}{|l|}{ Dipsadidae } \\
\hline $\begin{array}{l}\text { Atractus pantostictus } \\
\text { Fernandes \& Puorto, } 1994\end{array}$ & & & & & 2 & 2 \\
\hline $\begin{array}{l}\text { Echinanthera melanostigma } \\
\text { (Wagler in Spix, 1824) }\end{array}$ & 1 & & & & & 1 \\
\hline Erythrolamprus typhlus (Linnaeus, 1758) & & 4 & & & & 4 \\
\hline Oxyrhopus guibei Hoge \& Romano, 1978 & 1 & & 2 & & & 3 \\
\hline Philodryas olfersii (Lichtenstein, 1823) & & & & 1 & & 1 \\
\hline Sibynomorphus mikanii (Schlegel, 1837) & & & & & 1 & 1 \\
\hline Sibynomorphus neuwiedi (Ihering, 1911) & & & & & 1 & 1 \\
\hline Taeniophallus affinis (Günther, 1858) & & 1 & & & & 1 \\
\hline Xenodon merremii (Wagler in Spix, 1824) & & 6 & & 1 & & 7 \\
\hline \multicolumn{7}{|l|}{ Elapidae } \\
\hline Micrurus lemniscatus (Linnaeus, 1758) & & & & & 1 & 1 \\
\hline \multicolumn{7}{|l|}{ Viperidae } \\
\hline Bothrops jararaca (Wied, 1824) & 2 & & & & & 2 \\
\hline Bothrops neuwiedi Wagler in Spix, 1824 & & 1 & 2 & & & 3 \\
\hline Crotalus durissus (Linnaeus, 1758) & & & 1 & & & 131 \\
\hline TOTAL & 14 & 36 & 76 & 21 & 10 & 157 \\
\hline
\end{tabular}

recorded at the sampling site, of which four were unique to this environment. The only way to compare all the capture sets in this study was by means of capture efficiency, i.e. the ratio between the number of animals caught and the number of days for which the traps remained in place (Table 2).

The Cerrado sensu strictu areas had highest abundance $(\mathrm{n}=76)$, followed by the Cerradão area $(n=36)$. The lowest abundance was found 


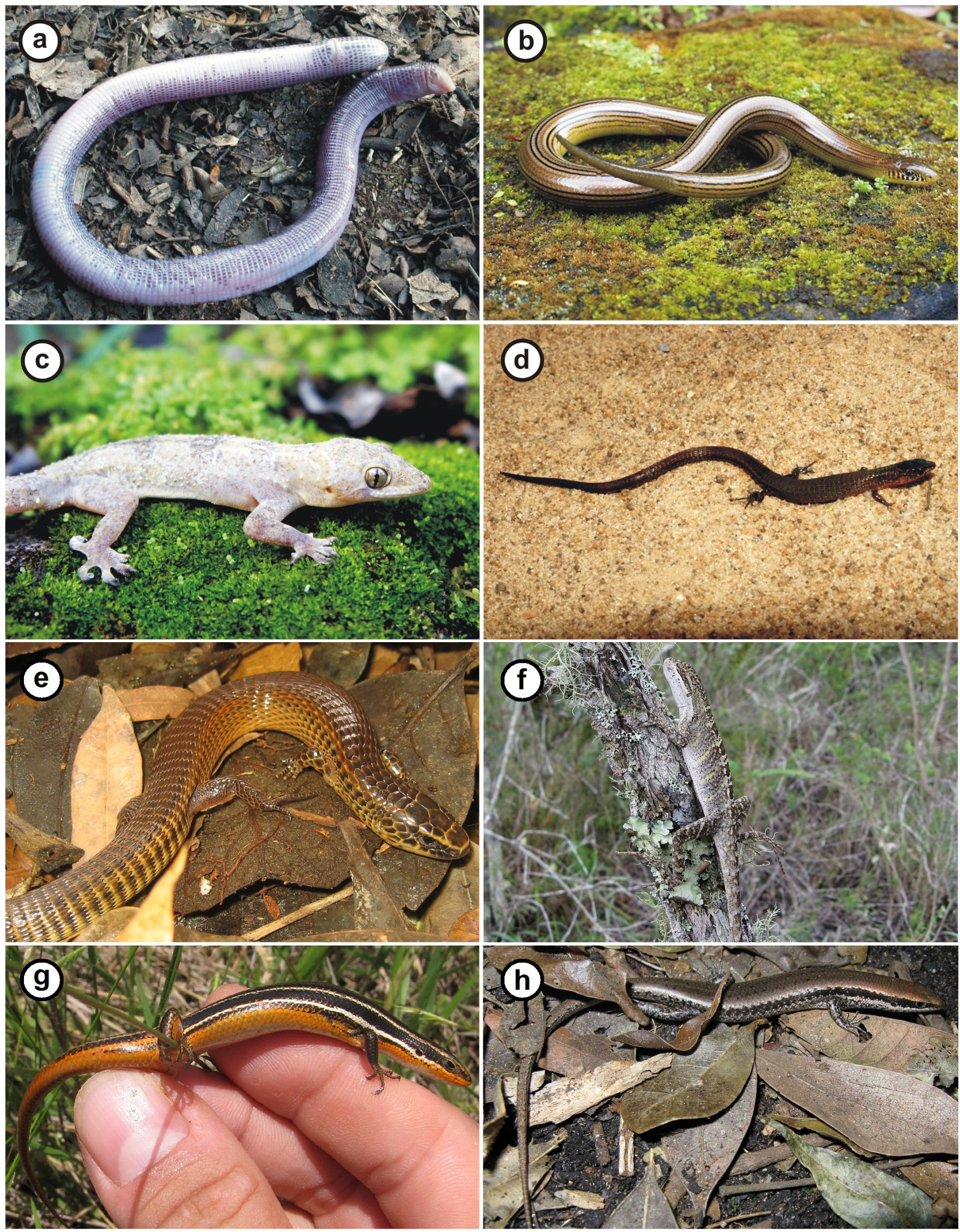

Figure 1. Squamata species recorded for the São José Mountains in Tiradentes, Minas Gerais. In a) Leposternon microcephalum, b) Ophiodes striatus, c) Hemidactylus mabouia, d) Ecpleopus gaudichaudi, e) Heterodactylus imbricatus, f) Enyalius bilineatus, g) Aspronema dorsivittatum, h) Notomabuya frenata . 

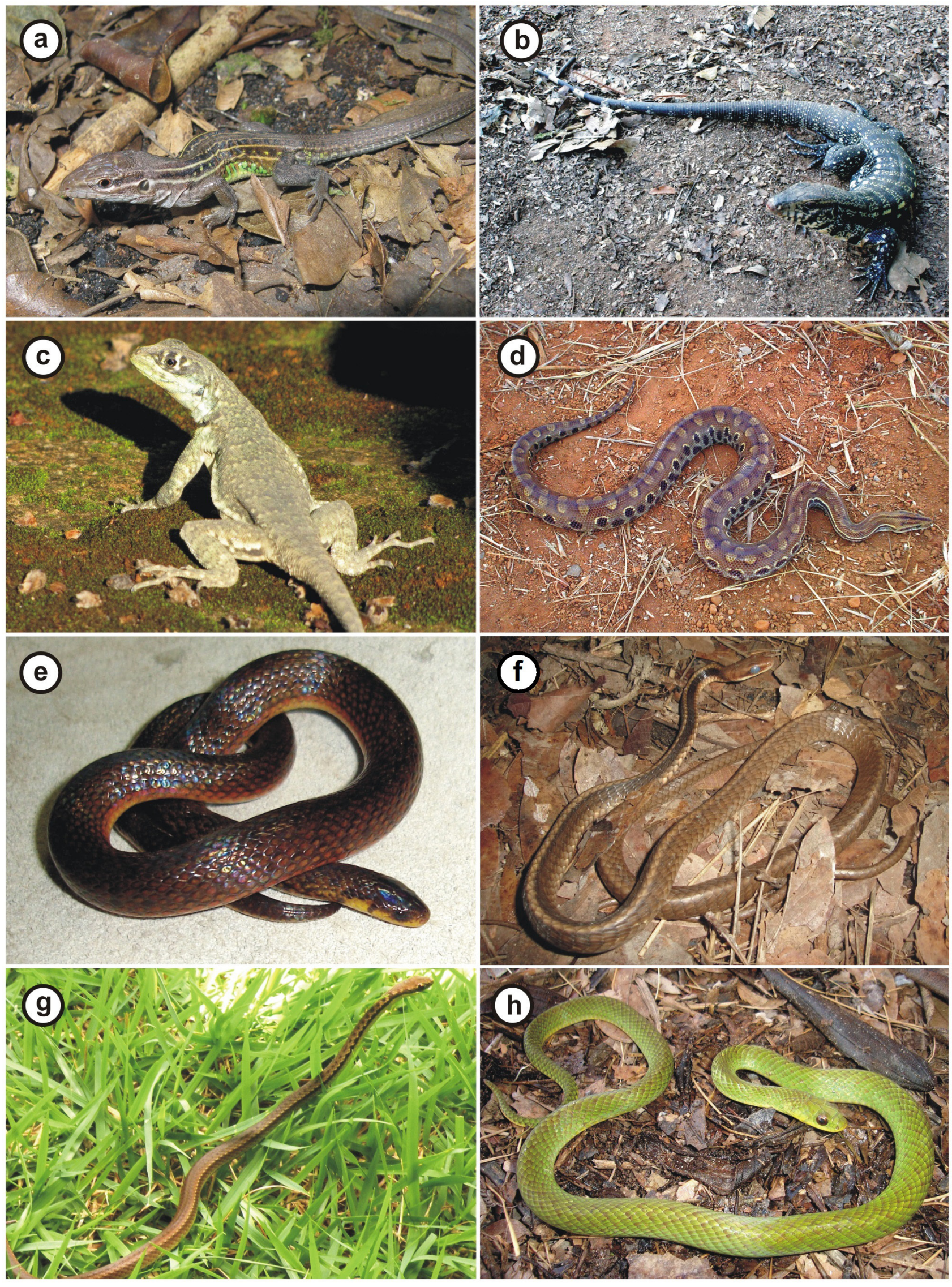

Figure 2. Squamata species recorded for the São José Mountains in Tiradentes, Minas Gerais. In a) Ameivula ocellifera, b) Salvator merianae, c) Tropidurus torquatus, d) Epicrates crassus, e) Atractus pantostictus, f) Chironius flavolineatus, g) Echinanthera melanostigma, h) Erythrolamprus typhlus. 


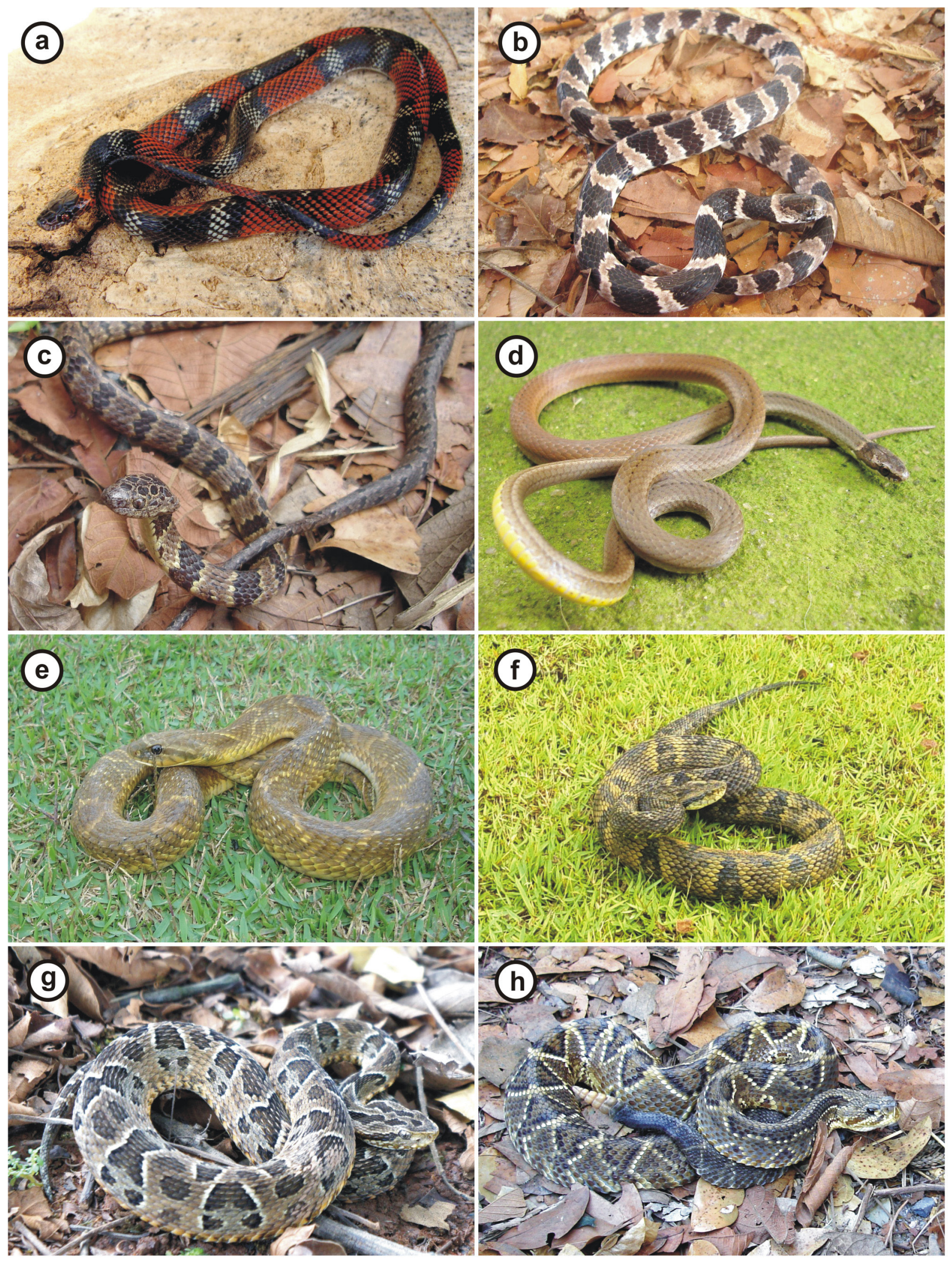

Figure 3. Squamata species recorded for the São José Mountains in Tiradentes, Minas Gerais. In a) Oxyrhopus guibei, b) Sibynomorphus mikanii, c) Sibynomorphus neuwiedi, d) Taeniophallus affinis, e) Xenodon merremii, f) Bothrops jararaca, g) Bothrops neuwiedi, h) Crotalus durissus. 


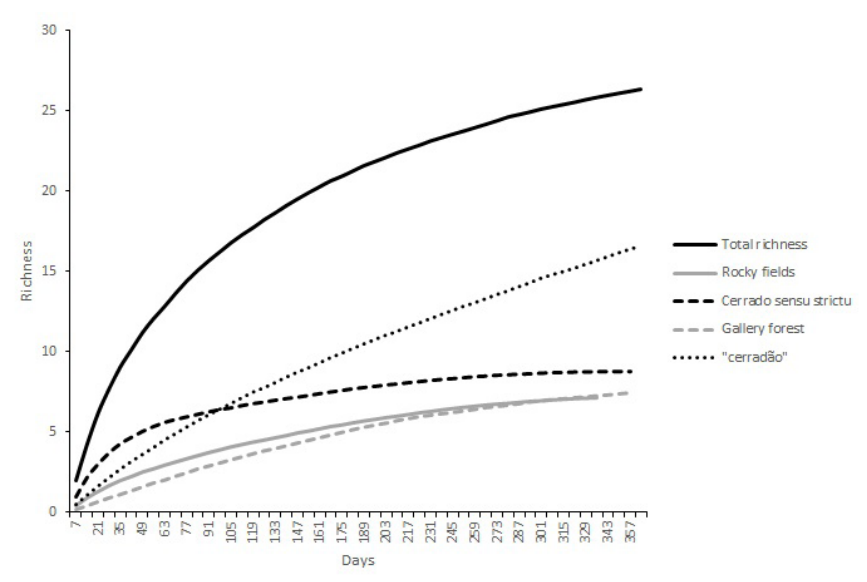

Figure 4. Accumulation curve of species of Reptilia in 1000 based randomization for each sampled vegetation type in the Conservation Area São José Mountains in Tiradentes, Minas Gerais between November 2009 and December 2010.

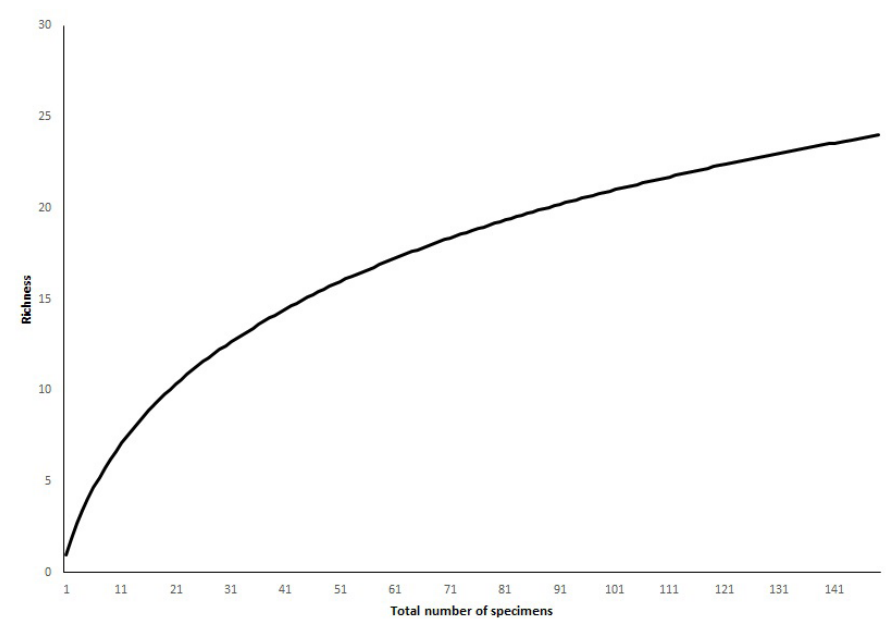

Figure 5. Accumulation curve of species of Reptilia in 1000 based randomization for total richness species in the Conservation Area São José Mountains in Tiradentes, Minas Gerais between November 2009 and December 2010.

in the gallery forest area $(n=14)$, but this was the vegetation type with the highest equitability. The greatest richness was found in the Cerradão area, with 13 species recorded. The areas that had highest diversity according to the three indexes were the Cerradão and gallery forest, respectively, as shown in Table 3.

The areas of Cerradão and Cerrado sensu strictu showed the greatest similarity $(\mathrm{CJ}=0.31)$, with presence of five species in common recorded. Bothrops neuwiedi $(\mathrm{n}=3)$ was the only species of snake sampled, and two of the three most abundant species of lizards in both environments were Enyalius bilineatus $(\mathrm{n}=32)$ and Ameivula ocellifera $(\mathrm{n}=19)$. The other similarity values are shown in Table 4.

The species with fossorial and subfossorial habits such as Leposternon microcephalum, Atractus pantostictus and Micrurus lemniscatus were recorded only through the chance encounter method, as also were Chironius quadricarinatus, Sibynomorphus mikanii and S. neuwiedi. The only specimen of $S$. neuwiedi was found hurt near one of the sampling sites, while Epicrates crassus and Hemidactylus mabouia were photodocumented in the Serra de São José, in rock field areas. This method proved of highly important, especially with regard to snakes, because among the 16 species recorded, six were sampled only through chance encounters (Table 5).
Table 2. Capture efficiency of Squamata specimens for each line of Fall Trap and Funnel Trap, held from November 2009 to November 2010, in the São José Mountains, Tiradentes, Minas Gerais.

\begin{tabular}{lcccc}
\hline \multicolumn{1}{c}{$\begin{array}{c}\text { Vegetation type and } \\
\text { Collection site }\end{array}$} & $\begin{array}{c}\text { Collection } \\
\text { days }\end{array}$ & Abundance & Richness & Eficiency \\
\hline $\begin{array}{l}\text { Gallery Forest - Águas } \\
\text { Santas }\end{array}$ & 244 & 1 & 1 & 0.004 \\
$\begin{array}{l}\text { Gallery Forest - Bosque } \\
\text { Mãe D'Água 2 }\end{array}$ & 390 & 3 & 3 & 0.008 \\
$\begin{array}{l}\text { Cerrado sensu strictu - } \\
\text { Águas Santas }\end{array}$ & 192 & 2 & 1 & 0.010 \\
$\begin{array}{l}\text { Gallery Forest - Bosque } \\
\text { Mãe D'Água 1 }\end{array}$ & 390 & 5 & 3 & 0.013 \\
Cerradão - Águas Santas & 275 & 4 & 2 & 0.015 \\
Cerradão - Coliseum 1 & 390 & 10 & 8 & 0.026 \\
Cerradão - Coliseum 2 & 390 & 15 & 9 & 0.039 \\
$\begin{array}{l}\text { Dirty Field - Coliseum } \\
\text { Cerrado sensu strictu - }\end{array}$ & 371 & 18 & 6 & 0.049 \\
Bosque Mãe D'Água & 390 & 29 & 7 & 0.074 \\
Cerrado sensu strictu - & 390 & 40 & 6 & 0.103 \\
Coliseum & & & & \\
\hline
\end{tabular}

Table 3. Richness, abundance, diversity and evenness in the vegetation types studied in the Serra de São José, Tiradentes, Minas Gerais.

\begin{tabular}{lcccc}
\hline Indices/Vegetation Type & $\begin{array}{c}\text { Dirty } \\
\text { Field }\end{array}$ & Cerrado & $\begin{array}{c}\text { Gallery } \\
\text { Forest }\end{array}$ & Cerradão \\
\hline Margalef Diversity (Dmg) & 1.64 & 1.36 & 3.06 & 2.28 \\
Simpson Diversity (1/D) & 2.41 & 4.04 & 5.40 & 6.33 \\
Shannon Diversity (H') & 1.26 & 1.55 & 1.74 & 2.06 \\
Shannon Equitability(J) & 0.70 & 0.80 & 0.97 & 0.89 \\
\hline
\end{tabular}

Table 4. Qualitative similarity of Jaccard (CJ) between vegetation types Dirty Field, Cerrado sensu strictu and Riparian Forest, studied in the Serra de São José, Tiradentes, Minas Gerais.

\begin{tabular}{lcccc}
\hline & Dirty Field & $\begin{array}{c}\text { Cerrado } \\
\text { sensu strictu }\end{array}$ & $\begin{array}{c}\text { Gallery } \\
\text { Forest }\end{array}$ & Cerradão \\
\hline Dirty Field & - & 0 & 0.09 & 0.14 \\
$\begin{array}{l}\text { Cerrado sensu } \\
\text { strictu }\end{array}$ & 0 & - & 0.08 & 0.31 \\
Gallery Forest & 0.09 & 0.08 & - & 0.23 \\
\hline
\end{tabular}

Table 5. Richness and abundance obtained according to each sampling methodology of reptiles in the Conservation Area São José Mountains in Tiradentes, Minas Gerais between November 2009 and December 2010. FT = Funnel Trap, PT = Pitfall Trap, $\mathrm{SLT}=$ Search limited by time, $\mathrm{OE}=$ Occasional Encounter.

\begin{tabular}{lccccc}
\hline & FT & PT & SLT & OE & Total \\
\hline Richness & 16 & 9 & 4 & 17 & $\mathbf{2 9}$ \\
Abundance & 66 & 62 & 8 & 21 & $\mathbf{1 5 7}$ \\
\hline
\end{tabular}

\section{Discussion}

It can be seen that the composition of the communities varied according to the vegetation gradient (physiognomy), which is consistent with the pattern recorded by Nogueira et al. (2011). The vegetation type with the highest abundance recorded was the Cerrado sensu strictu, where about $50 \%$ of the specimens were caught and collected, while the Cerradão had the highest richness and diversity with overlapping between species of open areas and those of gallery forest areas. The greater heterogeneity of the Cerradão and the fact that the largest number of species was recorded in this area in the present study are consistent with the theory of MacArthur \& MacArthur (1961), in which they stated that habitats with greater structural 
complexity tend to provide shelter for greater diversity. Although the traps used for sampling Squamata in this study are not ideal for tree-dwelling species and semi-arboreal species, the most abundant species in this study (E. bilineatus, which is semi-arboreal) was also more abundant in the Cerrado sensu strictu than in the gallery forest.

According to Nogueira et al. (2005) in a study in Cerrado areas, the lizard fauna is distributed in a mosaic, consisting of species with strict and predictable requirements as to the type of environment, which follow the habitat spots available. These data corroborate those found in the present study. However, one anthropic factor affecting the size of the populations of Squamata in the APA Serra de São José is fires. Large-scale fires occur frequently, and this was observed on the north side of the Sierra de São José and in the woods south of the mountain, during the period when this study was being developed.

Silva \& Bates (2002) considered that these forested areas play an important role in biodiversity conservation, through maintaining viable populations of typical forest species in Cerrado sensu strictu environments. Therefore, the greater similarity between the sampled areas of Cerradão and Cerrado sensu strictu in the present study can be explained through formation of mosaics of Cerradão forested areas with Cerrado sensu strictu areas and fields with sparse shrubs, thus forming environments that are more heterogeneous than the areas of gallery forest. This makes it possible both for animals typical of forest environments and for animals typical of open areas to occupy this type of habitat. In a study on herpetofauna associated with gallery forests in the Federal District, Brandão \& Araújo (2001) highlight the importance of forested environments in Cerrado areas, for maintaining local diversity.

According to Nogueira et al. (2005), the Cerrado provides great number of replacement species for nearby locations because of the mosaic of vegetation types. These authors studied the richness, fauna composition and local distribution of lizards in a 6,000 ha fragment in the Cerrado of central Brazil. They found that the richness values, with 17 sympatric species belonging to seven families outweighed most of the data from previous studies in Cerrado localities.

Representatives of the Squamata fauna studied here have been registered in other areas of the Cerrado, including Bothrops neuwiedi, Crotalus durissus, Chironius flavolineatus, Ameivula ocellifera, Enyalius bilineatus, Oxyrhopus guibei and Xenodon merremii (Bailey 1955, Teixeira-Filho et al. 1995; Nogueira 2001; France et al. 2008, Pinto et al. 2008; Sawaya et al. 2008); and in the Atlantic Forest, including Bothrops jararaca, Ecpleopus gaudichaudi, Erythrolamprus typhlus and Taeniophallus affinis (Di-Bernardo 1992; Marques et al. 2001; Feio \& Caramaschi 2002; São-Pedro Pires \& 2009; Condez et al. 2009). However, B. neuwiedi was also recorded in the Atlantic Forest area by França et al. (2012).

Among the lizards caught in the present study, only Salvator merianae, Ecpleopus gaudichaudii and H. imbricatus were not recorded by Nogueira et al. (2009) in Cerrado areas in central Brazil. However, Novelli et al. $(2011,2012)$ recorded H. imbricatus in gallery forest of this biome in the municipality of Ingaí in southern Minas Gerais. In the study by Cruz et al. (2014) in the Ouro Branco mountains, the species E. gaudichaudii was recorded, while H. imbricatus was recorded in riparian forest. These authors considered that these two species were endemic to the Atlantic Forest biome.

The genus Ecpleopus is currently considered to be monotypic, consequent to its last review by Uzzell (1969). However, recent molecular studies have indicated that it has greater taxonomic complexity. The evidence suggests that the name E. gaudichaudi may not apply to individuals in Minas Gerais and that there could soon be a new revision of the genus (Carolino 2010). This species was considered rare until a few years ago (Eisemberg et al. 2004), but expansion of the collection efforts has shown that this species is common, as reported by Dixo \& Verdade (2006) in forested areas of the Morro Grande Forest Reserve in Cotia, São Paulo, in which 54\% of the lizards caught belonged to this species.

Other records of reptile fauna in transition regions between the Atlantic Forest and Cerrado in Minas Gerais, near the study area, were also consulted. Sousa et al. (2010) found 29 species in the municipality of Ritápolis, of which 16 were also recorded in the present study. In Ouro Branco, out of the 28 species of snakes registered by São-Pedro \& Pires (2009), 10 were also found in the present study and by Silveira et al. (2010) in the municipalities of Ouro Preto, Mariana and Itabirito.

The richness of 29 species that was recorded in the present study was greater than in two other Squamata reptile surveys in similar environments of the Atlantic Forest, conducted by Ulisses \& Caramaschi (2002), who found richness of 11 species, and Gomides (2010), who found richness of 14 species. However, in most studies in similar areas, the species richness was greater than that presented in this survey (Silveira et al, 2010; Costa et al, 2010; Moura et al, 2012; Cross et al., 2014). This highlights the need for greater effort towards sampling of Squamata reptiles in the APA Serra de São José.

None of the rarefaction curves reached the full asymptote (Figure 4), which highlights the need for more studies and new data analysis methods, as seen in the study by Lopez et al. (2012), because of the high likelihood that new species may be recorded in the area studied. It is necessary to invest greater efforts in unsampled environments such as waterlogged fields and rock fields at the top of the São José mountains. Other important factors that influence the sampled data include the methods used for sample capture and collection. The methods that were used in the present study are the ones that are most used. However, further investments in searching for arboreal species are still needed, because this group was considered to be undersampled in this study.

The invasive species Hemidactylus mabouia is related to the urban environment, but has colonized rock areas near the study sites and presents high potential for colonization through occupying both preserved and degraded habitats, as previously also observed by Sousa \& Freire (2010). In the rock field area of the APA Serra de São José, one specimen of Epicrates was photographed in the vicinity of the municipalities of Tiradentes and Ritápolis. The species of Epicrates occurring in the collection area of the present study (Souza, 2011) may have been E. crassus, given that this species had been recorded by Sousa et al. (2010) in the municipality of Ritápolis. According to Passos \& Fernandes (2008), E. crassus is a species in the family Boidae, which is found in open areas, mainly in the southeastern and central-western regions of Brazil.

Among the snakes found, five have medical importance: the viperids Bothrops jararaca, Bothrops neuwiedi and Crotalus durissus, the elapid Micrurus lemniscatus and the dipsadid Philodryas olfersii. Accidents involving these snakes can be considered serious (Cardoso et al. 2003; Salomão et al. 2003).

None of the species recorded in this study present any level of threat on the IUCN list (2015), at national level (Machado et al. 2008) or at state level (COPAM 2010). However, H. imbricatus is classified as a "presumably endangered species" for the state of Minas Gerais (Biodiversitas 2007).

During this study, threats to the reptile fauna were detected at the sampling sites. The north face of the mountain range is subject to strong anthropic pressure, such as wood-cutting activities and the presence of tracks and garbage resulting from tourism. Next to the region chosen for evaluation on the north side of the mountain range is the entrance to the Mangue trail, which is greatly used for crossing the mountain range. Although the environments studied in the south of the APA are little affected by tourism, mainly because they are private areas, there is some pressure from hunters and there have been some reports of consumption of meat from Salvator merianae. Another threat to the local fauna that was noted is fires. Large fires have occurred in several consecutive years, including 
to the north of the study area during the experiment; and on September 9, 2012, when 480 hectares of forest were burned (Gazette 2012) on the south side of the Serra de São José. According to reports from residents, such occurrences are common in the APA. The number of plant and animal species registered, including new species, highlights the importance of the protected areas of the Serra de São José for maintenance of species diversity regionally and in the whole of the state of Minas Gerais. The most recent data available for the entire state come from the study by Bérnils et al. (2009). This area requires continual monitoring by the proper bodies, given its importance for the survival of several species that have been little studied or are unknown.

\section{Appendix}

Appendix 1. List of specimens collected and deposited at the Herpetological Collection-Reptiles of Universidade Federal de Juiz de Fora, Minas Gerais.

Ameiva ameiva, 788, 789, 790; Ameivula ocellifera, 786, 787, 798, 799, 801; Leposternon microcephalum, 782, 783, 813; Aspronema dorsivittatum, 802; Atractus pantostictus, 780, 781; Bothrops jararaca, 773, 775; Bothrops neuwiedi, 829; Chironius flavolineatus, 772; Chironius quadricarinatus 807; Echinanthera melanostigma, 797; Ecpleopus gaudichaudi, 793, 794, 814, 815; Enyalius bilineatus, 784, 777; Oxyrhopus guibei, 795, 806; Philodryas olfersii, 778; Sibynomorphus mikanii, 812; Sibynomorphus neuwiedi, 791; Tropidurus itambere, 796; Tropidurus torquatus, 774, 821, 822; Salvator merianae, 678; Xenodon merremii, 677, 805.

\section{Acknowledgements}

BM Sousa thanks the Foundation for Research Support of the State of Minas Gerais (FAPEMIG) by CRA for project financing - APQ-01992-09 (Notice 01/2009 - Demand Universal) of which this study is part and the National Council for Scientific and Technology Development (CNPq) for its Productivity Scholarship - PQ. C. H. Varela Rios CAPES - Higher Education Personnel Improvement Coordination for the scholarship granted. Novelli was supported by a Postdoctoral fellowship from PNPD / CAPES (National Program of Post Doctorate / Training Coordination of Higher Education Personnel, Brazil). The Brazilian Institute of Environment and Renewable Natural Resources (IBAMA / SISBIO) for permission to collect and transport specimens (registration 17917-1); the State Forestry Institute - IEF (Authorization 118/09); Marco Antonio de Sousa (in memorian), owner of the area called Coliseum, Luiz Ney de Assis Fonseca and Antonio Pedro dos Reis" of the area called the Bosque da Mãe D’Água, for allowing the installation of traps on their property.

\section{References}

ALVES, R.J.V. \& KOLBEK, J. 2009. Summit vascular flora of Serra de São José, Minas Gerais, Brazil. Check List 5(1):35-73.

ALVES, R.J.V. 1991. Guia de campo das orquídeas da Serra de São José, MG, Brasil. Editora Tropicaleaf.

ARAÚJO, C.O. \& ALMEIDA-SANTOS, S.M. 2011. Herpetofauna in a cerrado remnant in the state of São Paulo, Southeastern Brazil. Biota Neotrop. 11(3):47$61 \mathrm{http}: / /$ www.biotaneotropica.org.br/v11n3/en/abstract?article+bn00511032011

ÁVILA-PIRES, T.C.S. 1995. Lizards of the Brazilian Amazonia (Reptilia: Squamata). Zool Verh (Leiden), 299(1):1-706.

BAILEY, J.R. 1955. The snakes of the genus Chironius in southeastern South America. Occas. Pap. Mus. Zool. Univ. Mich. (571):1-21

BERNARDE, P. S. 2008. Ecologia e métodos de amostragem de Répteis Squamata. In Coletânea de textos - Manejo e Monitoramento de Fauna Silvestre em Florestas Tropicais. VIII Congresso Internacional Sobre Manejo de Fauna Silvestre na
Amazônia e América Latina (Silva, F.P.C., Gomes-Silva, D.A.P., Melo, J.S. \& Nascimento, V.M.L. eds), Rio Branco, AC, p. 189-201.

BERNILS, R.S., NOGUEIRA, C.C. \& XAVIER-DA-SILVA, V. 2009. Répteis. In Biota Minas: diagnóstico do conhecimento sobre a biodiversidade no Estado de Minas Gerais (G. M. Drummond, C.S. Martins, M.B. Greco \& F. Vieira, orgs.). Fundação Biodiversitas, Belo Horizonte, p.251-278.

BERTOLUCI, J., CANELAS, M.A.S., EISEMBERG, C.C., PALMUTI, C.F.S. \& MONTINGELLI, G.G. 2009. Herpetofauna of Estação Ambiental de Peti, an Atlantic Rainforest fragment of Minas Gerais State, southeastern Brazil. Biota Neotrop. 9(1):147-155 http://www.biotaneotropica.org.br/v9n1/en/ abstract?inventory+bn 01409012009

BIODIVERSITAS 2007. Lista das Espécies Presumivelmente Ameaçadas de Extinção da Fauna do Estado de Minas Gerais. Fundação Biodiversitas, Belo Horizonte.

BRANDÃO, R.A. \& ARAÚJO, A.F.B. 2001. A herpetofauna associada às matas de galeria no Distrito Federal. In Caracterização e Recuperação de Matas de Galeria (J.F. Ribeiro, C.E.L. Fonseca \& J.C. Sousa-Silva, eds.). Embrapa, Planaltina, p. 561-604.

BRITES, V.L.C. \& BAUAB, F.A. 1988. Fauna ofidiana do município de Uberlândia, Minas Gerais - Brasil. I. Ocorrência na área urbana. Rev. Cent. Cienc Biomed. UFU. 4:3-8.

BÖHM M. A., COLLEN B.A., BAILLIE, J. E.M. et al. 2013. The conservation status of the world's reptiles. Biol. Conserv. 157 (2013) 372-385.

CARDOSO, J.L.C., FRANÇA, F.O.S., WEN, F.H., MÁLAQUE, C.M.S. \& HADDAD JR, V. 2003. Animais peçonhentos do Brasil: biologia, clínica e terapêutica dos acidentes. Sarvier, São Paulo.

CAROLINO, D.M. 2010. Variação geográfica de Ecpleopus gaudichaudii (Squamata, Gmynophthalmidae) com base em caracteres morfológicos e moleculares. Dissertação de Mestrado, Universidade de São Paulo, São Paulo.

CARRASCO, P.A., MATTONI, C.I., LEYNAUD, G.C. \& SCROCCHI, G.J. 2012. Morphology, phylogeny and taxonomy of South American bothropoid pitvipers (Serpentes, Viperidae). Zool. Scr. 41:109-124.

CARVALHO, D.A. 1987. Composição florística e estrutura de cerrados do sudoeste de Minas Gerais. Tese de doutoramento, Universidade Estadual de Campinas, Campinas, São Paulo.

CECHIN, S.Z. \& MARTINS, M. 2000. Eficiência de armadilhas de queda (pitfall traps) em amostragens de anfíbios e répteis no Brasil. Rev Bras Zool. 17(3):729-740.

COLWELL, R.K. 2013. EstimateS: Statistical estimation of species richness and shared species from samples. Version 9.1.0 http://viceroy.eeb.uconn.edu/ estimates/ (último acesso em 25/06/2015)

CONDEZ, T.H., SAWAYA, R.J. \& DIXO, M. 2009. Herpetofauna dos remanescentes de Mata Atlântica da região de Tapiraí e Piedade, SP, sudeste do Brasil. Biota Neotrop. 9(1):1-29 http://www.biotaneotropica.

COPAM, 2010. DELIBERAÇÃO NORMATIVA COPAM No 147, DE 30 DE ABRIL DE 2010- Aprova a Lista de Espécies Ameaçadas de Extinção da Fauna do Estado de Minas Gerais. http://www.siam.mg.gov.br/sla/download. pdf?idNorma=13192 (último acesso em 21/06/2015)

COSTA, H.C. \& BÉRNILS, R.S. (org.). 2015. Répteis brasileiros: Lista de espécies 2015. Herpetologia Brasileira - 4(3):75-93. http://www.sbherpetologia.org. br/images/LISTAS/2014.03-07-MudancasTaxonomicas.pdf (último acesso em 01/06/2016)

CRUZ, A.J.R., DRUMMOND, L.O., LUCENA, V.D., MAGALHÃES, A.P., BRAGA, C.A.C., ROLIN, J.M. \& PIRES, M.R.S. 2014. Lizard fauna (Squamata, Sauria) from Serra do Ouro Branco, Southern Espinhaço Range, Minas Gerais, Brazil. Check List 10(6): 1290-1299. http://dx.doi.org/10.15560/10.6.1290 (último acesso em 25/06/2015)

DI-BERNARDO, M. 1992. Revalidation of the genus Echinanthera Cope, 1894, and its conceptual amplification (Serpentes, Colubridae). Comun. Mus. Ciênc. PUCRS. Sér. Zool. 5(13): 225-256.

DIXO, M. \& VERDADE, V.K. 2006. Herpetofauna de Serrapilheira da Reserva Florestal de Morro Grande, Cotia (SP). Biota Neotrop. 6(2):1-20 http://www. biotaneotropica.org.br/v6n2/pt/abstract?article+bn00806022006. ISSN 1676-0603

DOAN, T.M. \& ARRIAGA, W.A. 2002. Microgeographic variation in species composition on the hepetofaunal communities of Tambopata Region, Peru. Biotropica 34(1):101-117. 
DRUMMOND, G.M., MARTINS, C.S., MACHADO, A.B.M., SEBAIO, F.A. \& ANTONINI, Y. 2005. Biodiversidade em Minas Gerais: um Atlas para sua conservação. 2 ed. Fundação Biodiversitas, Belo Horizonte, Minas Gerais.

FEIO, R.N. \& CARAMASCHI, U. 2002. Contribuição ao conhecimento da herpetofauna do nordeste do estado de Minas Gerais, Brasil. Phyllomedusa. 1(2):105-111.

FRANÇA, F.G.R. FRANÇA, R. C.; GERMANO, C.E.S. \& OLIVEIRA FILHO. J.M 2012. Bothropoides neuwiedi (Wagler, 1824) (Squamata: Serpentes: Viperidae) Distribution extension for the Atlantic Forest, first vouchered record for Paraíba, and geographic distribution map. Check List. 8(1):170-171

FROST, D.R., ETHERIDGE, R., JANIES D. \& TITUS, T. 2001. Total Evidence, Sequence Alignment, Evolution of Polychrotid Lizards, and a Reclassification of the Iguania (Squamata: Iguania). Amer. Mus. Nat. Hist. 3343, 38p

GAZETA, 2012. Chamas destroem quase 500 hectares de serras. Gazeta de São João del-Rei em 15/09/2012. http://www.gazetadesaojoaodelrei.com.br/site/2012/09/ chamas-destroem-quase-500-hectares-de-serras/ (último acesso em 26/01/2015)

GOMIDES, S.C. 2010. Diversidade da fauna de Squamata em fragmentos florestais urbanos de Juiz de Fora, Minas Gerais, Brasil. Dissertação de Mestrado, Universidade Federal de Juiz de Fora, Juiz de Fora, Minas Gerais.

GREENBERG, C.H., NEARY, D.G. \& HARRIS, L.D. 1994. A comparison of herpetofaunal sampling effectiveness of pittfall, single-endede, and doubleended funnel traps used with drift fences. J. Herpetol. 28(3):319-324.

HEDGES, S. B. \& CONN, C. E. 2012. A new skink fauna from Caribbean island (Squamata, Mabuyidae, Mabuyinae). Zootaxa 3288 (2012): 1-244.

HUDSON, A.A. 2007. Diversidade e aspectos ecológicos e comportamentais de serpentes da Estação Ecológica de Anavilhanas, Amazônia Central, Brasil Dissertação de Mestrado, Universidade Federal de Juiz de Fora. Juiz de Fora, Minas Gerais.

IUCN 2015. IUCN Red List of Threatened Species. Version 2015.2. http//www. iucnredlist.org (último acesso em 25/06/2015)

LOPEZ, L.C.S., FRACASSO, M.P.D., MESQUITA, D.O., PALMA, A.R.T., \& RIUL, P. 2012. The relationship between percentage of singletons and sampling effort: a new approach to reduce the bias of richness estimates. Ecol. Indic 14 (2012): 164-169.

LUCAS, P.S, NOVELLI, I.A \& SOUSA, B. M. 2016. Assemblage of squamate reptiles in a natural remnant of Cerrado in southern Minas Gerais, Brazil. Check List 12 (2): 1866.

MACARTHUR, R.H. \& MACARTHUR, J.W. 1961. On bird species diversity. Ecology 42(3):594-598.

MACHADO, A.B.M., DRUMMOND, G.M. \& PAGLIA, A.P. 2008. Livro vermelho da fauna brasileira ameaçada de extinção. Volume II. Fundação Biodiversitas, Brasília / Belo Horizonte.

MAGURRAN, A.E. 2004. Mesuring Biological Diversity. Blackwell Science, Oxford

MARINHO-FILHO, J., R.B. MACHADO, R.P.B. HENRIQUES. 2010. Evolução do conhecimento e da conservação do Cerrado Brasileiro. In Cerrado: conhecimento científico quantitativo como subsídio para ações de conservação. (I.R. Diniz, J. Marinho-Filho, R.B. Machado, R.B. Cavalcanti, eds). Thesaurus, Brasília, DF, p. 15-34.

MARQUES, O.A.V., ETEROVICK, A. \& SAZIMA, I. 2001. Serpentes da Mata Atlântica: guia ilustrado para a Serra do Mar. Ed. Holos, Ribeirão Preto.

MITTERMEIER, R.A., GIL, P.R., HOFMANN, M., PILGRIM, J., BROOKS, T., MITTERMEIER, C.G., LAMOREAUX, J. \& FONSECA, G.A.B. 2004 Hotspots revisited: Earth's biologically richest and most endangered terrestrial. Cemex, Washington.

MOURA, M.R., MOTTA, A.P., FERNANDES, V.D. \& FEIO, R.N. 2012. Herpetofauna da Serra do Brigadeiro, um remanescente de Mata Atlântica em Minas Gerais, Sudeste do Brasil. Biota Neotrop. 12(1):209-235 http://www.biotaneotropica. org.br/v12n1/en/abstract?inventory+bn01012012012

NOGUEIRA, C., VALDUJO, P.H. \& FRANÇA, F.G.R. 2005. Habitat variation and lizard diversity in a Cerrado area of Central Brazil. Stud. Neotrop. Faun. Environ. 40(2):105-112.

NOGUEIRA, C., COLLI, G.R. \& MARTINS, M. 2009. Local richness and distribution of the lizard fauna in natural habitat mosaics of the Brazilian Cerrado. Austral Ecol. 34(1):83-96.
NOGUEIRA, C.; RIBEIRO, S.; COSTA, G.C. \& C.R.GUARINO. 2011. Vicariance and endemism in a Neotropical savanna hotspot: distribution patterns of Cerrado squamate reptiles. J. Biogeogr 2011 (38):1907-1922.

NOVELLI, I.A., LUCAS, P.S. \& SANTOS, R.C. 2011. Reptilia, Squamata, Gymnophthalmidae, Heterodactylus imbricatus Spix, 1825: Filling gaps in the state of Minas Gerais. Check List 7(1):30-31.

NOVELLI, I.A., LUCAS, P.S., CARVALHO, R.G., SANTOS, R.C. \& SOUSA, B.M. 2012. Lagartos de áreas de Cerrado na Reserva Biológica UnilavrasBoqueirão, Ingaí, Sul de Minas Gerais, Brasil. Biota Neotrop. 12(3):01-07 http://www.biotaneotropica.org.br/v12n3/pt/abstract?inventory+bn00312032012 ISSN 1676-0603

OLIVEIRA-FILHO, A.T. \& MACHADO, J.N.M. 1993. Composição florística de uma floresta semidecídua montana na Serra de São José, Tiradentes, Minas Gerais. Acta. Bot. Bras. 7(2):71-88. org.br/v9n1/en/abstract?inventory+bn01809012009

PAGLIA, A.P., BERNILS, R.S. \& DEVELEY, P.F. 2010. A luta pela proteção dos vertebrados terrestres. Edição especial scientific American, Brasil.

PASSOS, P. \& FERNANDES, R. 2008. Revision of the Epicrates cenchria Complex (Serpentes: Boidae). Herpetol. Monogr. 22:1-30.

PETERS, A. J., DONOSO-BARROS R. \& OREJAS-MIRANDA, B. 1986. Catalogue of neotropical squamata Part I: Snakes - Part II: Lizards and amphisbaenians. With new material by P. E. Vanzolini. Smithsonian Institution Press Washington, D. C., and London.

PINTO, R.R., FERNANDES, R. \& MARQUES, O.A.V. 2008. Morphology and diet of two sympatric colubrid snakes, Chironius flavolineatus and Chironius quadricarinatus (Serpentes: Colubridae). Amphibia-Reptilia 29(2):149-160.

PROBIO. 2004. Áreas prioritárias para a conservação, utilização sustentável e repartição de benefícios da Biodiversidade Brasileira. CD-ROM. Projeto de Conservação e Utilização Sustentável da Diversidade Biológica Brasileira. Ministério do Meio Ambiente, Brasília, DF.

PYRON, R. A., BURBRINK, F. T. \& WIENS, J. J. 2013. A phylogeny and revised classification of Squamata, including species of lizards and snakes. BMC Evol. Biol. 13: 93. doi:10.1186/1471-2148-13-93

RECODER, R. \& NOGUEIRA, C. 2007. Composição e diversidade de répteis squamata na região sul do Parque Nacional Grande Sertão Veredas, Brasil Central. Biota Neotrop. 7(3):267-278 http://www.biotaneotropica.org.br/v7n3/ pt/abstract?inventory+bn01107032007. ISSN 1676-0603

RODRIGUES, M.T. 1987. Sistemática, ecologia e zoogeografia dos Tropidurus do grupo torquatus ao Sul do Rio Amazonas (Sauria, Iguanidae). Arq. Zool 31(3):105-230

SALOMÃO, M.G., ALBOLEA, A.B., ALMEIDA-SANTOS, S.M. 2003. Colubrid snakebite: a public health problem in Brazil. Herpetol. Rev. 34:307-312.

SANTOS, A.J. 2003. Estimativas de riqueza em espécies. In Métodos de estudos em biologia da conservação e manejo da vida silvestre (L. CullenJR., R. Rudran \& C. Valladares-Padua, orgs). UFPR, Curitiba, p.19-41.

SANTOS, R.C., LUCAS, P.S., SOUSA, B.M. \& NOVELLI, I.A. 2009. Reptilia, Squamata, Leiosauridae, Urostrophus vautieri: Distribution extension and geographic distribution map. CheckList 5(3):533-536.

SÃO-PEDRO, V.A. \& PIRES, M.R.S. 2009. As Serpentes da Região de Ouro Branco, extremo sul da Cadeia do Espinhaço, Minas Gerais. Rev. Ceres 56(2):166-171.

SAWAYA, R.J., MARQUES, O.A.V. \& MARTINS, M. 2008. Composição e história natural das serpentes de Cerrado de Itirapina, São Paulo, sudeste do Brasil. Biota Neotrop. 8(2):127-149 http://www.biotaneotropica.org.br/v8n2/en/abst ract?inventory+bn01308022008

SILVA, J.M.C. \& BATES, J.M. 2002. Biogeographic patterns and conservation in the South American Cerrado: a tropical savanna hotspot. Bioscience 52:225-233.

SILVA, N.G., ALVES, R.J.V., PEREIRA, J.F. \& RIVADAVIA, F. 2011. Lentibulariaceae, Serra de São José, Minas Gerais, Brazil. Check List 7(2):120-127.

SILVEIRA, A.L.; PIRES, M.R.S. \& COTTA, G.A. 2010. Serpentes de uma área de transição entre o Cerrado e a Mata Atlântica no Sudeste do Brasil. Arq Mus Nac Rio J. 68(1-2):79-110.

SOUSA, B.M., NASCIMENTO, A.E.R., GOMIDES, S.C., VARELA RIOS, C.H., HUDSON, A.H. \& NOVELLI, I.A. 2010. Répteis em fragmentos de Cerrado e Mata Atlântica do Campo das Vertentes, Estado de Minas Gerais, Sudeste 
do Brasil. Biota Neotrop. 10(2):129-138 http://www.biotaneotropica.org.br/ v10n2/en/abstract?article+bn03510022010

SOUSA, P.A.G. \& FREIRE, E.M.X. 2010. Communal nests of Hemidactylus mabouia (Moreau de Jonnès, 1818) (Squamata: Gekkonidae) in a remnant of Atlantic Forest in northeastern Brazil. Biotemas 23(3):231-234.

SOUZA, M.M. de 2011. A vida sobre pedras. Terra da Gente 7(81):24-29.

UETZ, P. 2016. The EMBL Reptile database. http://www.reptile-database.org/dbinfo/news.html (último acesso em 13/06/2016)

UZZELL, T.M. 1969. The status of the genera Ecpleopus, Arthroseps and Aspidolaemus (Sauria, Teiidae). Postilla. 135:1-23.
VELOSO, H.P., RANGEL-FILHO, A.L.R. \& LIMA, J.C.A. 1991. Classificação da vegetação brasileira adaptada a um sistema universal. IBGE, Rio de Janeiro.

ZANELLA, N. \& CECHIN, S.Z. 2006. Taxocenose de serpentes no Planalto Médio do Rio Grande do Sul, Brasil. Rev Bras Zool. 23(1):211- 217.

Received: $17 / 08 / 2015$

Revised: 29/10/2016

Accepted: 08/12/2016

Published online: 16/01/2017 